\title{
ANÁLISE DOS ASPECTOS ECONÔMICOS DO TURISMO RELIGIOSO EM BOM JESUS DA LAPA-BA
}

\author{
Cynara Santo-Sé Alves ${ }^{1}$ \\ Deyse Queiróz \\ Paula Renata
}

\begin{abstract}
RESUMO
O turismo religioso alavanca a economia em muitos países e municípios, chegando a compor o Produto Interno Bruto (PIB) de algumas cidades do Brasil, constituindo um gerador de renda para diferentes setores da economia local. Essa pesquisa teve como objetivo compreender a importância do turismo religioso para Bom Jesus da Lapa-Ba e quais as consequências e estratégias utilizadas pelo comércio para movimentar o mercado econômico mediante a nova realidade (covid-19). A metodologia utilizada foi a abordagem qualitativa através da pesquisa de campo, no qual se aplicou, para coleta de dados, um questionário e entrevista semiestruturada aos comerciantes do município. Essa investigação constatou que o turismo religioso é de total importância para Bom Jesus da Lapa-Ba, sendo o principal fator que movimenta a economia. Ademais boa parte do seguimento comercial sofreu consequências drásticas em decorrência da pandemia, ressaltando que utilizaram novas estratégias comerciais para manter as vendas.
\end{abstract}

Palavras-chaves: Turismo religioso. Pandemia. Estratégias. Comércio. Fé.

\section{ANALYSIS OF THE ECONOMIC ASPECTS OF RELIGIOUS TOURISM IN BOM JESUS DA LAPA-BA}

\begin{abstract}
Religious tourism leverages the economy in many countries and municipalities, making up the Gross Domestic Product (GDP) of some cities in Brazil, constituting an income generator for different sectors of the local economy. This research aimed to: Understand the importance of religious tourism for Bom Jesus da Lapa-Ba and what are the consequences and strategies used by commerce to move the market through the new reality (covid-19). The methodology used was a qualitative approach through field research, in which a questionnaire and semi-structured interview with merchants in the municipality were applied for data collection. This investigation found that religious tourism is of total importance for Bom Jesus da Lapa-Ba, being the main factor that drives the economy. Furthermore, much of the commercial segment suffered drastic consequences as a result of the pandemic, noting that they used new commercial strategies to maintain sales.
\end{abstract}

Keywords: Religious tourism. Pandemic. Strategies. Business. Faith.

\section{ANÁLISIS DE LOS ASPECTOS ECONÓMICOS DEL TURISMO RELIGIOSO EN BOM JESUS DA LAPA-BA}

\section{RESUMEN}

${ }^{1}$ Docente UNEB. caalves@uneb.br. 
El turismo religioso apalanca la economía en muchos países y municipios, constituyendo el Producto Interno Bruto (PIB) de algunas ciudades de Brasil, constituyendo un generador de ingresos para diferentes sectores de la economía local. Esta investigación tuvo como objetivo: Comprender la importancia del turismo religioso para Bom Jesus da Lapa-Ba y cuáles son las consecuencias y estrategias que utiliza el comercio para mover el mercado a través de la nueva realidad (covid-19). La metodología utilizada fue un enfoque cualitativo a través de investigación de campo, en la cual se aplicó un cuestionario y entrevista semiestructurada con comerciantes del municipio para la recolección de datos. Esta investigación encontró que el turismo religioso es de suma importancia para Bom Jesus da Lapa-Ba, siendo el principal factor que impulsa la economía. Además, gran parte del segmento comercial sufrió consecuencias drásticas como resultado de la pandemia, destacando que utilizaron nuevas estrategias comerciales para mantener las ventas.

Palabras clave: Turismo religioso. Pandemia. Estrategias. Negocio. Fe.

\section{Introdução}

O Turismo religioso é ligado à religião, atraindo um público de todos os lugares com a finalidade de participar de romarias, conhecer lugares históricos como igrejas, grutas, templos., sempre no exercício da fé e busca pela espiritualidade. Essa modalidade vem ganhando cada vez mais espaço no mercado financeiro porque aquece a economia em muitas cidades pelo mundo, que atrai pessoas sejam pela fé, ou até mesmo por curiosidade. Mas, também, é uma realidade que vem sendo estudada por teóricos que detalham os principais aspectos dessa modalidade de turismo. Sua importância é significativa, compondo o Produto Interno Bruto (PIB) de algumas cidades pelo Brasil, no qual, além do fator econômico, é um gerador de renda para diferentes setores, como hotéis, transporte, restaurantes, e o ramo do entretenimento. Nesse contexto, existe, também, o fator social que com ele envolve a cultura, costumes, dos membros daquela comunidade, ou seja, é uma área que abrange o todo da sociedade.

Atualmente, o mundo enfrenta uma nova realidade, vive-se tempos difíceis, dias de incertezas, vidas interrompidas, negócios fechando as portas, novas modalidades de empregos etc. Causados por um vírus letal e transmissível, o covid-19 também conhecido coronavírus, é uma doença infecciosa e recém-descoberta, que está sendo estudada para que a propagação do vírus seja interrompida, visto que, gerou inúmeras vítimas. Aparecida do Norte, Bom Jesus da Lapa-BA, Juazeiro do Norte-CE e Nova Trento-SC, são os destinos mais procurados por visitantes. Nessa perspectiva criou-se 
uma nova modalidade lives, a siberdevoção que na atualidade muitas pessoas já tem acesso a meios de comunicação tecnológicos. Já que se tornou impossível eventos religiosos em plena pandemia.

Nessa perspectiva, Santos (2020) discute em seu trabalho sobre o turismo religioso pelo mundo e sua adaptação em tempos de pandemia com a nova modalidade há uma preocupação do meio religioso em manter fortalecido o vínculo de devotos. Oliveira (2017), traz uma abordagem sobre o turismo religioso em Aparecida do Norte e sua influência local, no brasil e no mundo. Santos e Severo (2018), analisa em seu trabalho a influência da fé cristã na economia através do marketing e do turismo religioso em Camboriú e Nova Trento-SC. Nogueira (2013), discute sobre os eventos religiosos e sua importância no desenvolvimento da região em Juazeiro do Norte. Um dos setores mais atingidos pelo vírus foi o turismo, de modo que, o número de viagens, passeios, excursões teve uma queda significativa, isso porque o isolamento social é indispensável para diminuir a contaminação, ou seja, por um tempo viagens foram canceladas, afetando economicamente as cidades que dependem do turismo para o desenvolvimento local.

O intuito deste trabalho é entender a importância do turismo religioso na cidade de Bom Jesus da Lapa, município do estado da Bahia, uma cidade de grande potencial turístico que atrai inúmeras pessoas por ano, com o propósito de conhecer pontos turísticos como a gruta de pedra e luz e o rio São Francisco além da culinária local, entre outros.

O estudo é de extrema relevância não só para a comunidade acadêmica como também para a sociedade que passará a entender mais sobre o assunto. Nessa concepção, sente-se a necessidade de analisar os aspectos do turismo religioso em Bom Jesus da Lapa. Com isso, analisa-se: Compreender a importância do turismo religioso para Bom Jesus da Lapa-Ba e quais as consequências e estratégias utilizadas para movimentar o mercado da mesma, com a nova realidade?

Desse modo, o objetivo geral da pesquisa dessa pesquisa é: Compreender a importância do turismo religioso para Bom Jesus da Lapa-Ba e quais as consequências e estratégias utilizadas para movimentar o mercado da mesma, com a nova realidade. Para o alcance do objetivo geral contamos com os seguintes objetivos específicos são: 
entender a partir de quando surgiu o turismo religioso em Bom Jesus da Lapa; analisar todas as vertentes do turismo religioso; investigar as esferas comerciais que mais crescem no turismo religioso de Bom Jesus da Lapa e como está sendo em período de pandemia; analisar as principais estratégias para o crescimento econômico dos comerciantes.

Para a realização da pesquisa, foi escolhido, a abordagem qualitativa, com a finalidade de entender o turismo religioso em Bom Jesus da Lapa, junto com a pesquisa exploratória e descritiva, através de livros, trabalhos acadêmicos e sites. E uma observação juntamente com questionários para os sujeitos dessa pesquisa. Na primeira seção trata-se do surgimento do turismo religioso em Bom Jesus da Lapa, bem como seu desenvolvimento. Na segunda seção, do turismo religioso nas cidades brasileiras e o crescimento econômico. Onde descreve algumas cidades pelo Brasil que tem essa espécie de turismo. Na terceira seção, fala-se sobre o turismo e desenvolvimento, destacando sua importância nas cidades. E na quarta e última seção, será tratado sobre como a pandemia atingiu de maneira direta no turismo.

\section{Turismo Religioso, Cidades Brasileiras e Crecimento Econômico}

O turismo é atividade que gera benefícios para todos os membros de uma comunidade. Nessa perspectiva, Teixeira (2016) enfatiza que atualmente cresce cada vez mais a compreensão de que o turismo é uma atividade econômica, tendo grande influência em diversos setores como religioso, político, cultural, ecológico e rural. Ainda de acordo com o mesmo autor, cabe aqui acrescentar que diferentemente de outras atividades econômicas, esta necessita de um percentual menor de investimento, isso porque utiliza-se de recursos do próprio contexto no qual se insere, como maneira de investimento turístico. No entanto, o que mais cresce economicamente nessa atual conjuntura é o turismo religioso. Este tipo de turismo aparentemente é novo, porém era uma prática constante dos nobres medievais que iam em grupo em busca do lugar sagrado, eles caracterizavam essa ação como peregrinação, no qual todos iam em busca de espirito nos lugares tidos como sagrados (PINTO, 2006). Nos dias atuais, o turismo religioso é praticado por pessoas que procuram a fé em diversas manifestações religiosas, procissões, missas, festas da igreja, entre outras, com o intuito de buscar 
respostas para seus problemas (PINTO, 2006). Destaca-se, de outros tipos de turismo pois têm características que se igualam ao turismo cultural, afinal de contas surgiu de alguma determinada cultura de um povo (ARDIGÓ, 2016). Ademais, é necessário que se busque alternativas para o desenvolvimento, que suprem as demandas de todos os envolvidos do contexto, tendo um grande enfoque para o benefício de todos e para a valorização de seus patrimônios, como já foi citado acima é que se deve ter um grande olhar para a conservação da cultura da cidade (DIAS, 2010). Os destinos mais procurados no Brasil são: o santuário de Aparecida do Norte em São Paulo, Bom Jesus da Lapa, na Bahia, Juazeiro do Norte no Ceará e Nova Trento em Santa Catarina. Essas cidades têm como objetivo principal promover a cidade e o comércio e com princípio maior atrair cada vez mais o número de pessoas a cada ano, através de estratégias que atualmente são por meios de comunicação. A exemplo do crescimento do turismo religiosos nas cidades brasileiras, dentre as citadas Santa Catarina teve um grande avanço, de acordo com Ardigó (2016) teve como consequência um advento “ a beatificação de madre Paulina, e sua canonização, em maio de 2002 pelo papa João Paulo II, a cidade que já possuía uma relação com a religiosidade, passou a receber um número crescente de peregrinos de todo o país e do exterior." Podemos analisar aqui que com a beatificação cresceu os números de fieis turistas nessa cidade. Como também a construção do santuário de Santa Paulina como ilustrado na Figura 1 o números de fiéis aumentou consideravelmente.

Figura 1- Santuário de Santa Paulina-SC.

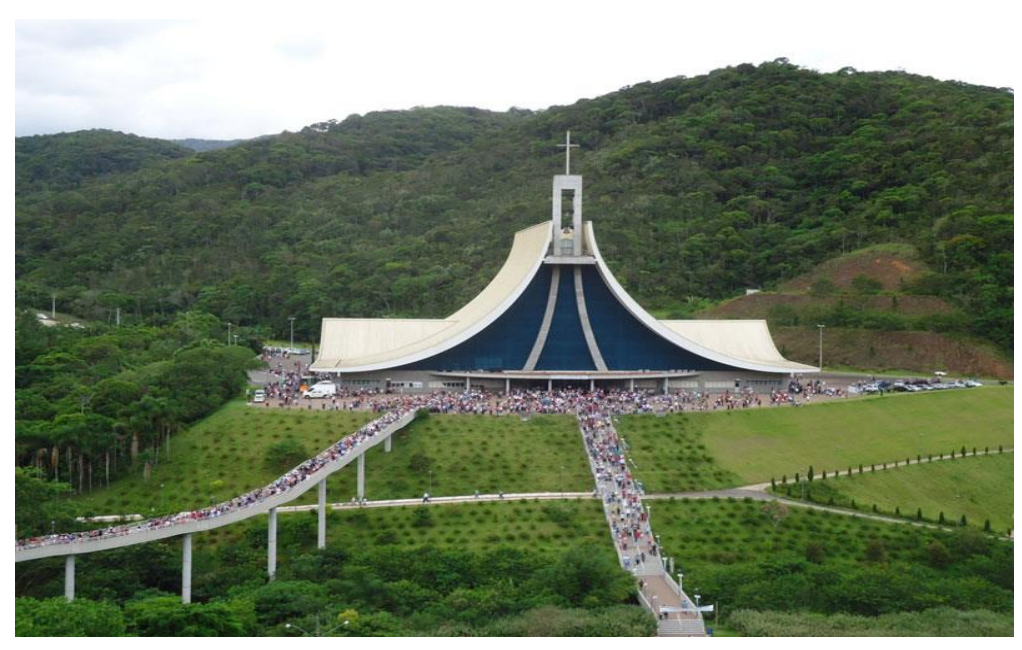

Fonte: SC Turismo (2019). 
Já em Juazeiro do norte, os romeiros viajam até a cidade de pau de arara, ônibus, esses são os transportes mais comuns por eles, é característicos deles também, sempre ir em grupos e cantando os benditos, em devoção a padre Cícero, assim se concentram milhares de fiéis o ano todo, em alguns momentos até fica intransitável, pois eles deslocam para diversos lugares da cidade em grande aglomeração, os principais: Estátua do Padre Cícero, de 27 metros de altura, a trilha do Santo Sepulcro, e Museu Vivo Padre Cícero, na Colina do Horto Fig.(2); Basílica de Nossa Senhora das Dores onde começa a história do Juazeiro; Capela do Perpétuo Socorro, onde está enterrado o Padre Cícero; Santuário do Coração de Jesus, mantido pelos salesianos; e o Santuário de São Francisco (PEREIRA, 2015). Podemos analisar aqui como já foi citado acima, a maioria dos pontos turísticos, e que tem mais concentração são patrimônios históricos e naturais da cidade. Como apontado na Figura 2 a imagem do Padre Cícero é um grande atrativo de Juazeiro do norte-CE.

Figura 2- Estátua de Padre Cícero em Juazeiro do Norte-Ce.

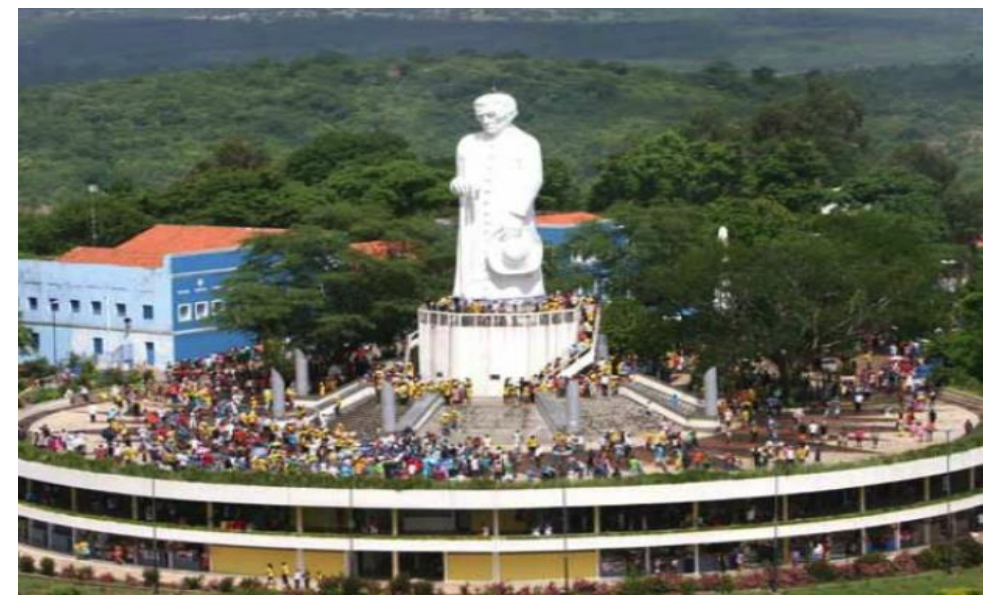

Fonte: Bessa (2015).

Cabe aqui acrescentar a maior romaria do Brasil e também compreende o maior culto mariano do mundo, Aparecida do Norte que reúne milhares de fiéis o ano todo, o fluxo de pessoas é ainda maior em outubro, quando ocorre romaria de aparecida na basílica nova situada no interior de São Paulo, além disso, os visitantes aproveitam a 
oportunidade para conhecer a cidade e fazer compras, movimentando a economia local (PINTO, 2006).

Salienta-se que a romaria de aparecida do norte é reconhecida mundialmente e é de extrema importância para a cidade e para o país, pois atrai turistas de outros países para conhecer a cidade, passando por pontos turísticos, conhecendo a cultura, gastronomia, fatores esses que aquecem a econômia e auxilia no desenvolvimento local. A cidade de Aparecida do Norte em São Paulo, recebe um grande público de pessoas anualmente, especialmente em outubro, quando é festejado o dia de nossa senhora Aparecida, a padroeira do Brasil. A Figura 3 mostra como é o fluxo de pessoas nesse período de romaria.

\section{Figura 3- Santuário de Aparecida do Norte-Aparecida-SP.}

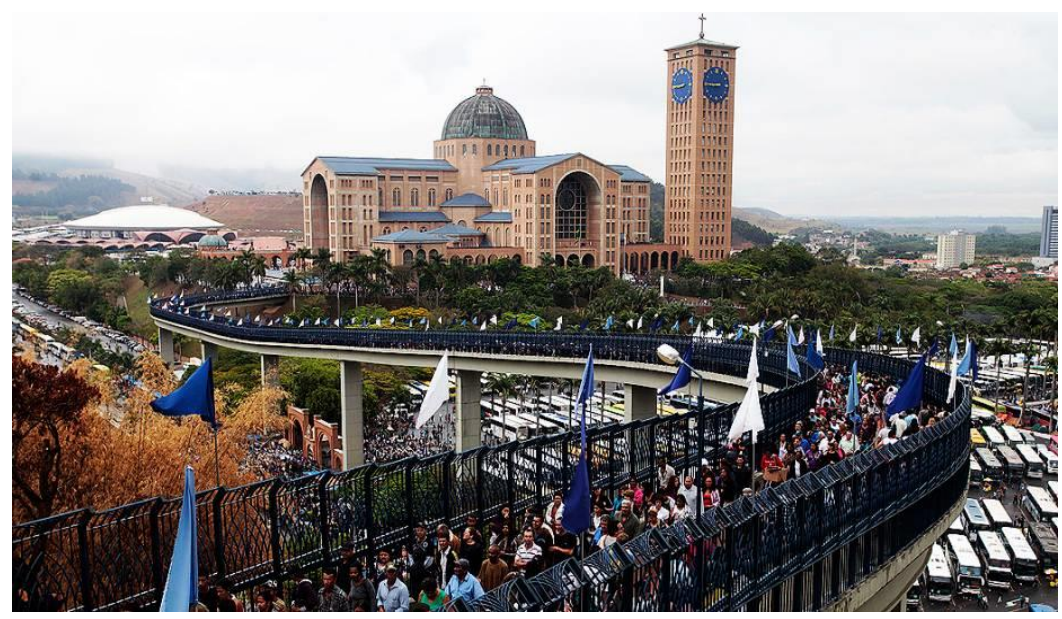

Fonte: Veja (2012).

A cidade de Bom Jesus da Lapa é conhecida como capital baiana da fé, é palco da segunda maior romaria do Brasil, de acordo com Ribeiro (2010) no mês de agosto especificamente visita-se Bom Jesus milhares de pessoas todos os anos, o que difere Bom Jesus da Lapa das demais é o morro e as grutas, que traz um ar de espiritualidade e místico. Além disso, há outros pontos turísticos como a barrinha, o rio São Francisco e a catedral de Nossa senhora do Carmo. Esses pontos são os mais frequentados por romeiros e turistas que circulam sempre em grupo. Nessa perspectiva, cabe aqui enfatizar que esta cresce a cada ano, beneficiando a igreja, comerciantes e toda população que se prepara para trabalhar nessa época. São muitas as pesquisas nesse 
contexto da romaria de Lapa (como carinhosamente é chamada), porém a lacunas como, por exemplo, saber quais as estratégias os comerciantes estão aderindo para o sucesso econômico que cresce a cada ano. A Figura 4 ilustra o festejo na última romaria antes da pandemia, e o número de romeiros ali presentes, renovando sua fé.

Figura 4- Romaria de Bom Jesus da Lapa- BA.

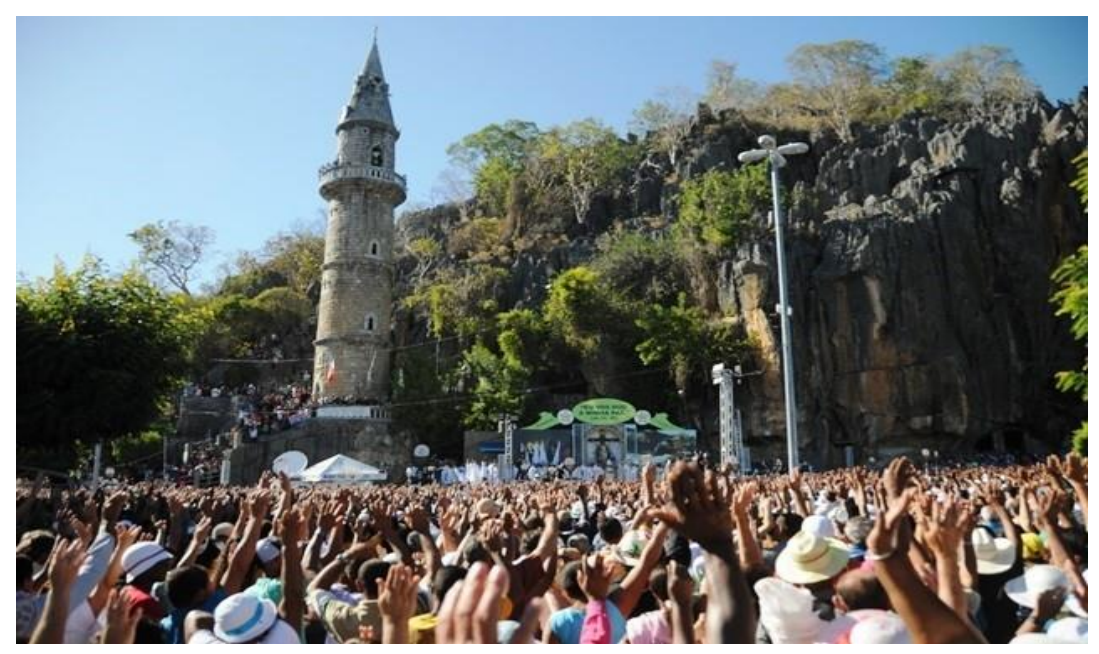

Fonte: Rodrigues (2019).

Imagem da romaria de 2019, com os romeiros na explanada do Bom Jesus, professando sua fé e agradecendo as graças alcançadas.

\subsection{Conceito histórico e surgimento do turismo em Bom Jesus da Lapa-BA}

Bom Jesus da Lapa é uma cidade localizada no oeste do estado da Bahia, sua história é sempre lembrada e contada todos anos nos períodos de romaria, à relatos que após a chegada do monge Francisco de Mendonça Mar em 1691, segundo histórias populares, o monge abrigou-se em uma caverna, fazendo ali sua morada, trazendo com ele a imagem do Bom Jesus crucificado e a imagem de nossa senhora da Soledade, a partir daí pessoas foram atraídas para a gruta e nesse ambiente místico faziam pedidos e orações.

Com o passar do tempo, os números de visitantes iam aumentando, se tornando tradição na cidade e com isso desenvolveu-se o santuário do Bom Jesus, como hoje é conhecido, vale ressaltar que Francisco desempenhava um papel social importante, 
ajudando os pobres e idosos que necessitavam de cuidados na região. Vale lembrar que além de visitantes da região, visitantes de outras localidades passavam pelo povoado e se hospedavam em pousadas, desde então começou o turismo religioso como é conhecido atualmente.

O surgimento de vários santuários começou a distinguir-se em locais afastados das cidades, em meio à natureza inóspita. $\mathrm{Na}$ austeridade desses locais desabitados e isolados, o aparecimento desses templos propiciou o desenvolvimento das comunidades locais. $\mathrm{O}$ fato importante a destacar é que ocorreram deslocamentos contínuos de pessoas em toda a história da humanidade cuja origem motivacional principal era de cunho religioso.(MAIO, 2003, p.3)

Para os moradores da cidade a uma valorização desse aspecto econômico, pois é uma grande fonte de renda da cidade, em que tudo gira em torno do turismo, além da preocupação não só das autoridades locais, como também dos comerciantes que dependem do turismo religioso, em preparar a cidade para receber turistas. É importante destacar, o trabalho da igreja nesse contexto de preparação e organização da Lapa, pois tudo é realizado em virtude da programação dessa entidade, tendo como maior preocupação manter a fé dos romeiros.

Steil ressalta:

Podemos ver nesses posicionamentos a disputa por dois legados deixados pelo monge fundador do santuário: o espiritual e o material. Se entre os moradores prevalece a reivindicação do legado material, para o clero trata-se de salvar a "religiosidade e a fé dos romeiros" sem perder a hegemonia sobre os negócios e a arrecadação financeira que a romaria realiza.(STEIL, 2003, p.5).

\section{Ao longo tempo, essa peregrinação foi se tornando cada vez mais} comum, aumentando o número de pessoas ano pós ano, e atualmente é uma das romarias mais visitadas do país. A também conhecida capital baiana da fé, Bom Jesus da Lapa é sede de uma das maiores romarias do Brasil ocupando terceiro lugar, atraindo pessoas de todos os lugares do Brasil e do mundo, Bom Jesus da Lapa é uma cidade conhecida por ser acolhedora e receptiva.

Alguns setores são de fundamental importância para Lapa, pois através deles, é possível movimentar o mercado da mesma, esses fatores econômicos movem a 
econômia de Bom Jesus da Lapa como: a pesca, a agricultura, a pecuária, o comércio, o turismo, prestação de serviços, entre outros. (JESUS; PIRES; ARAÚJO,2016)

Nesse contexto, entende-se que o turismo foi a primeira atividade econômica da cidade que porém não é a única, ou seja, o turismo é um fator econômico importante para a cidade, mas que em períodos que não ocorrem as romarias na cidade, de fevereiro a maio, há outros setores para aquecer o mercado, não sendo fortemente impactada nesses períodos. De junho a janeiro, a cidade atende uma demanda maior de pessoas e consequentemente haverá a requisição de produtos e serviços, bem como alimentação, hospedagem, entretenimento, entre outros serviços, vale ressaltar a importância de aprimorar esses meios de produtos e serviços a serem prestados a esse público. Essas vertentes do turismo religioso iniciaram-se há alguns séculos com os primeiros peregrinos que visitavam a vila e a cada ano após foi crescendo e se desenvolvendo. Nos tempos atuais, além de gerar renda e emprego para os moradores, geram também oportunidade para pessoas de outras localidades, que veem na romaria, uma oportunidade de comercializar seus produtos já que nesse período o público tem um aumento considerável.

\subsection{Turismo e Desenvolvimento}

O Desenvolvimento está diretamente ligado ao crescimento econômico das cidades, visto que, engloba elementos essenciais para a população tais como: saúde, segurança, educação e ao bem-estar social de todos os componentes da sociedade, numa cidade turística é reforçado tal importância, pois os beneficiários vão além dos membros daquela comunidade. O turismo surge como uma alternativa para o desenvolvimento local de muitas cidades pelo mundo, é uma estratégia imprescindível para crescimento da cidade.Para Nogueira (2013), Crescimento e desenvolvimento foi uma alternativa desenvolvida por países no pós segunda guerra para que o pib alavancasse, uma vez que a renda do país não era suficiente. A partir daí esses países buscaram alternativas para o desenvolvimento do país, explorando as riquezas locais. Nessa conjuntura, o turismo se tornou o principal gerador de renda de cidades, seja religioso, cultural ou de consumo, o turismo é essencial para que cidades países e municípios se desenvolvam, pois assim, a qualidade de vida dos moradores aumenta e inevitavelmente a geração de emprego. 
Para que haja desenvolvimento econômico a experiência histórica ensina que é essencial que as instituições garantam, em primeiro lugar, a ordem pública ou a estabilidade política, em segundo lugar, o bom funcionamento do mercado, e, em terceiro lugar, boas oportunidades de lucro que estimulem os empresários a investir e inovar. (PEREIRA, 2006, p.6).

Deve-se ter uma atenção para atenção voltada a esse crescimento, pois é uma relação ganha-ganha tanto do setor público, garantindo estabilidade, segurança e abertura comercial. E assim haja investimento por parte dos empresários que consequentemente irá gerar mais oportunidade de emprego, além da cidade se tornar mais atrativa para turistas.

Santos e Severo (2018) ressaltam que a peregrinação é algo comum no Brasil, inúmeras pessoas viajam para cidades com santuários, para pagar promessas, e agradecer as graças recebidas, por acreditarem que milagres acontecem nesses lugares que para eles são sagrados. A fé inabalável desses fiéis movimenta cidades inteiras, pois a uma preparação das mesmas pra recepcioná-los, o que possibilita o investimento do governo do estado voltado para o turismo religioso na economia local.

Os períodos de romarias deixam as cidades com o fluxo intenso a Lapa recebe o público para romaria a partir de junho se estendendo até janeiro, por ano milhares de visitantes passam pela cidade, os períodos mais intensos são em agosto na romaria do Bom Jesus e em setembro na romaria de nossa senhora da Soledade. Nesse período, Bom Jesus da Lapa comporta uma maior quantidade de pessoas.

[...] O turismo religioso produz uma cadeia produtiva, além de usufruir todas as atividades econômicas dos lugares visitados, envolve o conjunto de fornecedores e projetos finais que arrecadam com o consumo dos turistas e com as atividades tipicamente voltadas para $\mathrm{o}$ turista, como a venda de passagens, as estadas em hotéis, pousadas, dentre outros serviços. O consumo envolve uma realidade mais ampla da comunidade receptora. Nessas cidades santuários, há presença constante do comércio anexada à atividade religiosa, onde se vendem os artigos de interesse dos peregrinos, restaurantes, farmácias e artigos religiosos, além dos estacionamentos e alojamentos.(TEIXEIRA, 2016, p.8).

Esses conjuntos de fatores que formados pelo turismo, são fundamentais para o desenvolver da sociedade, vale lembrar que essas necessidades devem ser atendidas, os 
eventos religiosos necessitam da colaboração do comércio para que possa fluir de maneira harmoniosa, como também, o comércio dessas cidades dependem de eventos religiosos para se manterem. Ou seja, ambas andam lado a lado. Com o cenário atual, a princípio tornou-se inviável passeios turísticos, viagens, entre outros. Algumas alternativas foram tomadas para que a vontade de viajar permaneça. O turismo é compreendido como uma fonte de recurso benéfica para cidades, países e municípios economicamente falando e do ponto de vista espiritual é entendido como um alimento para a alma.

\subsection{Turismo e Pandemia}

Muitos setores na economia enfrentam uma grande dificuldade com a atual realidade, o surto do COVID-19 que impossibilitou áreas como por exemplo: o turismo, que em todos os locais foram proibidas viagens, eventos, afetando não só empresas de passagens aéreas, como também as cidades que recebem esse público, é um setor que teve queda por conta do coronavírus.

O surto de coronavírus levou os governos de muitos países a impor restrições às viagens não essenciais aos países afetados pelo COVID19, suspendendo indefinidamente viagens de turismo, vistos de trabalho e vistos de imigrantes. Alguns países proibiram completamente todas as formas de viagem para dentro ou para fora de suas fronteiras, fechando todos os aeroportos do país. ( KHATIB, 2020, p.5).

Essa preocupação dos países em manter a população em território tem como objetivo principal impedir que o vírus propague entre as pessoas, para que o número de vítimas diminua, isso porque muitos tiveram vidas interrompidas causados pelo COVID-19, em contrapartida, muitos estabelecimentos tais como: empresas, hotéis, restaurantes, entre outros, foram obrigados a fecharem por período indeterminado.

Essa política de distanciamento social dificultou alguns ramos de entretenimento e laser, que com o passar do tempo foi se agravando a situação. Isso porque é uma doença recente, e as políticas públicas ainda não são eficazes para que esses negócios se mantenham, como também não está sendo suficiente para a diminuição da contaminação.

Políticas como a 'política de permanência em casa' e a 'política de distanciamento social' ou "política de isolamento social" danificaram 
gravemente a renda de restaurantes, bares, lojas e hotéis em muitos locais, em alguns casos resultando no fechamento. Destruiu muitas empresas no setor de hospitalidade de maneira que não eram previstas, e o governo falhou em assumir a responsabilidade pelo fracasso de pequenas e grandes empresas que não sobreviveram ao surto de coronavírus devido à política de distanciamento social imposta pelo governo e restrições de bloqueio. Ou a política de distanciamento social foi implementada muito cedo ou a política foi levada ao extremo por cidadãos e viajantes que tinham medo de patrocinar essas empresas por medo de contrair a doença COVID-19. (KHATIB, 2020, p.13)

Há um certo receio em viajar em período pandêmico, mesmo que necessário pois o risco de contrair a doença é grande, portanto, os habitantes seguem medidas impostas pelo governo, que é ficar em casa, mantendo o isolamento social, com o intuito de se proteger contra a doença.

De acordo com Santos (2020, p.16) ouve uma preocupação do meio religioso em manter fortalecido o vínculo de devotos mantendo assim uma forte conexão, que em meio a pandemia, os santuários transformaram os encontros em ciber-encontros para manter a segurança dos romeiros, além disso, com a impossibilidade deles se locomoverem aos santuários, as imagens foram transportadas pelas ruas, no intuito de manter a tradição. Nesse contexto é observado uma preocupação da igreja em manter os devotos, mesmo que no mundo virtual, dando continuidade as crenças e devoções de sus fiéis. Que estão impossibilitados de manter os costumes existentes há milhares de anos. Não obstante, alguns setores tiveram queda significativa, com parada do turismo, alguns meios buscam uma saída para enfrentar esse problema, não ficando para trás, a igreja católica resolveu aderir o meio digital como a internet, antes era bem utilizado por determinado público, mas não com a mesma proporção que atualmente. Rádio e televisão são os meios de transmissão mais utilizados, nos tempos atuais, abriu-se espaço para a internet. Na cidade de Bom Jesus da Lapa, em período de pandemia, houve melhorias na infraestrutura de pontos turísticos das cidades e ao redor do santuário para melhor receber turistas e romeiros quando passar esse período pandêmico. Com a nova realidade que o mundo enfrenta, a romaria de Bom Jesus da Lapa, no ano de 2020 foi realizada virtualmente assim mantendo a tradição mesmo que de outra forma, após 320 anos de história e de romarias as celebrações virtuais são a 
única opção para os festejos, para que assim seja preservado a saúde dos romeiros e visitantes.

\section{Procedimentos Metodológicos}

A pesquisa aqui demonstrada é de natureza qualitativa por assim se caracterizar, por se tratar de fenômenos da educação, ela possibilita ao pesquisador maior participação no processo e resultados que serão obtidos na pesquisa (MARCONI; LAKATOS, 2007).Quanto ao tipo de pesquisa, a escolha foi pela Pesquisa de Campo, que se trata da obtenção da coleta de dados em campo, ele permite ao pesquisador que ele tenha contato com o pesquisado em seu ambiente. Nesse contexto, foi adotado entrevista e questionário para a coleta de dados da pesquisa. Quanto aos objetivos ela se caracteriza como descritiva e exploratório, com o objetivo de entender o turismo religioso visto que envolver levantamento bibliográfico, entrevistas com pessoas que sabem mais sobre o objeto de pesquisa, ela se diferencia das demais, pois utiliza-se de técnicas padronizadas de coletas de dados, tais como: questionário e observação (GIL, 2008).

Dessa maneira, instrumento utilizado foi a entrevista semiestruturada. $\mathrm{Na}$ entrevista semiestruturada é preciso ter perguntas que possibilitem o entrevistado a ter um diálogo aberto com o pesquisador, é direcionado para grupos específicos, além disso é necessário uma naturalidade ao passar de uma pergunta para outra e o pesquisador pode criar novas perguntas dentro do contexto caso suja alguma dúvida que seja necessária para a compreensão do fenômeno pesquisado. (MANZINI,2012). Dessa maneira, na análise de dados os entrevistados foram decodificados com E1 e E2 (entrevistados 1 e 2). A análise dos dados foi feita pela Triangulação por apresentar três aspectos importante para o estudos dos fatos pesquisados, o primeiro aspecto consiste no levantamento de dados concretos e as narrativas dos entrevistados; o segundo aspecto refere-se ao discussões de autores que estudam o assunto e por fim o terceiro aspecto está no conjunto de circunstâncias que de uma forma generalizada da realidade.(MARCONDES,2014).

\section{Resultados e Discussões}


Nesta seção será apresentado os resultados e análises das discussões da pesquisa de campo. Foram entrevistados duas pessoas, dentre elas, um lojista e um empresário do ramo hoteleiro que responderam questões sobre esses setores da economia lapense. Foi realizado também um questionário com 35 pessoas que trabalham neste circuito da economia .

O questionário foi desenvolvido através do google forms e enviado via WhatsApp para os participantes, por conta do período pandêmico, para manter a segurança dos envolvidos. Alguns participantes da pesquisa optaram por responder as questões do questionário no local de trabalho, tomando todas os cuidados e medidas de distanciamento, realizado com os vendedores ambulantes e vendedores que se situam em boxs próximos a gruta, esse processo contribuiu para identificar os fatores econômicos presentes em Bom Jesus da Lapa, tais como a sua importância e desenvolvimento.

Sabe-se que o turismo não é o único gerador de renda da Lapa, de acordo com o gráfico (1), mas é considerado um dos mais importantes, de modo que há uma preocupação por parte dos setores público e do privado na realização de melhoria na cidade para que se torne mais atrativa, visto que o cenário atual dificulta a movimentação desse mercado neste primeiro gráfico é apresentada a importância do turismo religioso em Bom Jesus da Lapa-Ba, segundo seus participante.

\section{Gráfico 1- Qual a importância do turismo religioso para Bom Jesus da Lapa}




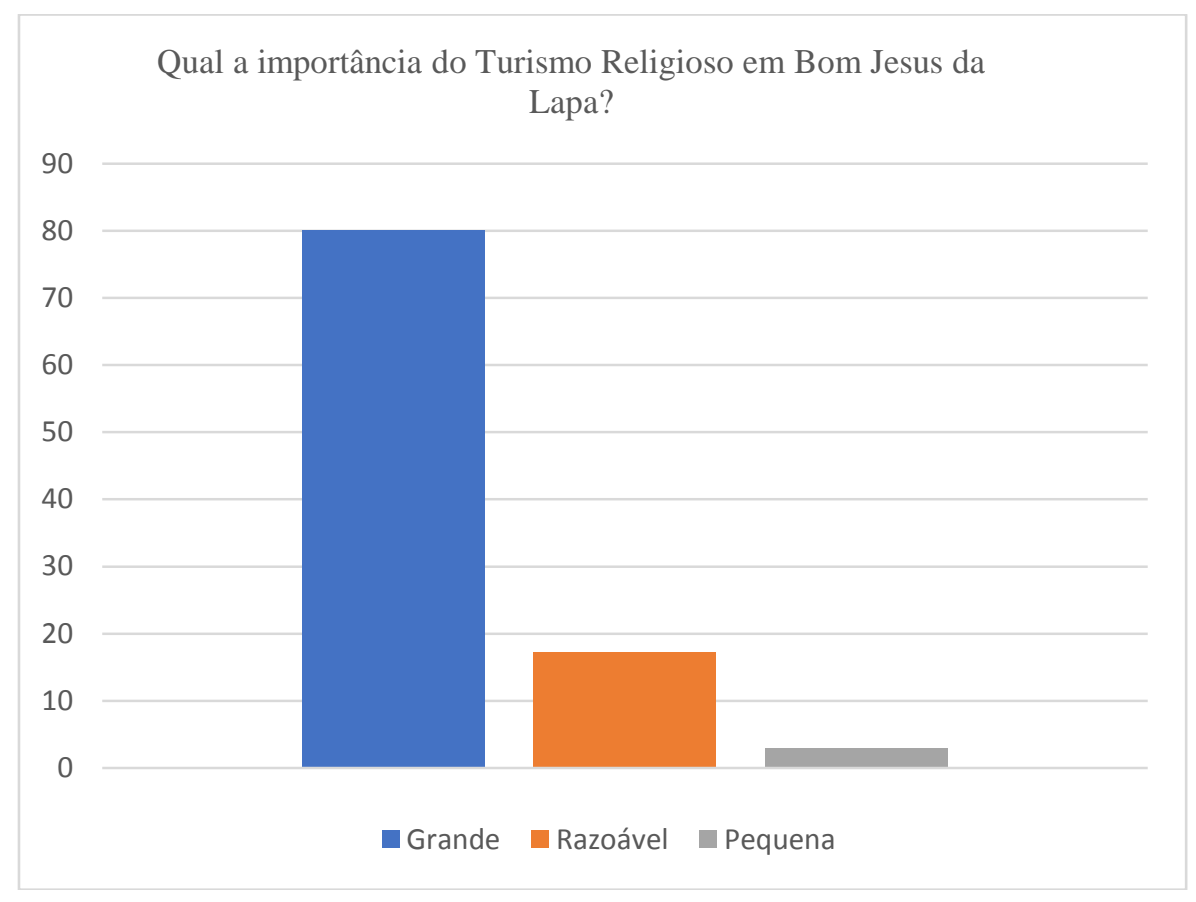

Fonte: Dados da Pesquisa (2021)

Para $80.0 \%$ o turismo religioso é de grande importância para a cidade. $17.1 \%$ dos participantes consideram a importância do turismo religioso razoável. 2.9\% considera pequena a importância do turismo religioso em Bom Jesus da Lapa. De acordo com Almeida (2019), o turismo religioso é de extrema relevância para o crescimento econômico da cidade, pois muda boa parte dos setores, ocasionando um significativo desenvolvimento do local; além disso contribui também para o meio cultural e a valorização das tradições.

No gráfico 2, observa-se que a maioria dos participantes dependem exclusivamente do turismo religioso para sobreviver, evidenciando esse fator econômico de total importância para o município.

Gráfico 2- Você depende exclusivamente do turismo religioso para sobreviver? 


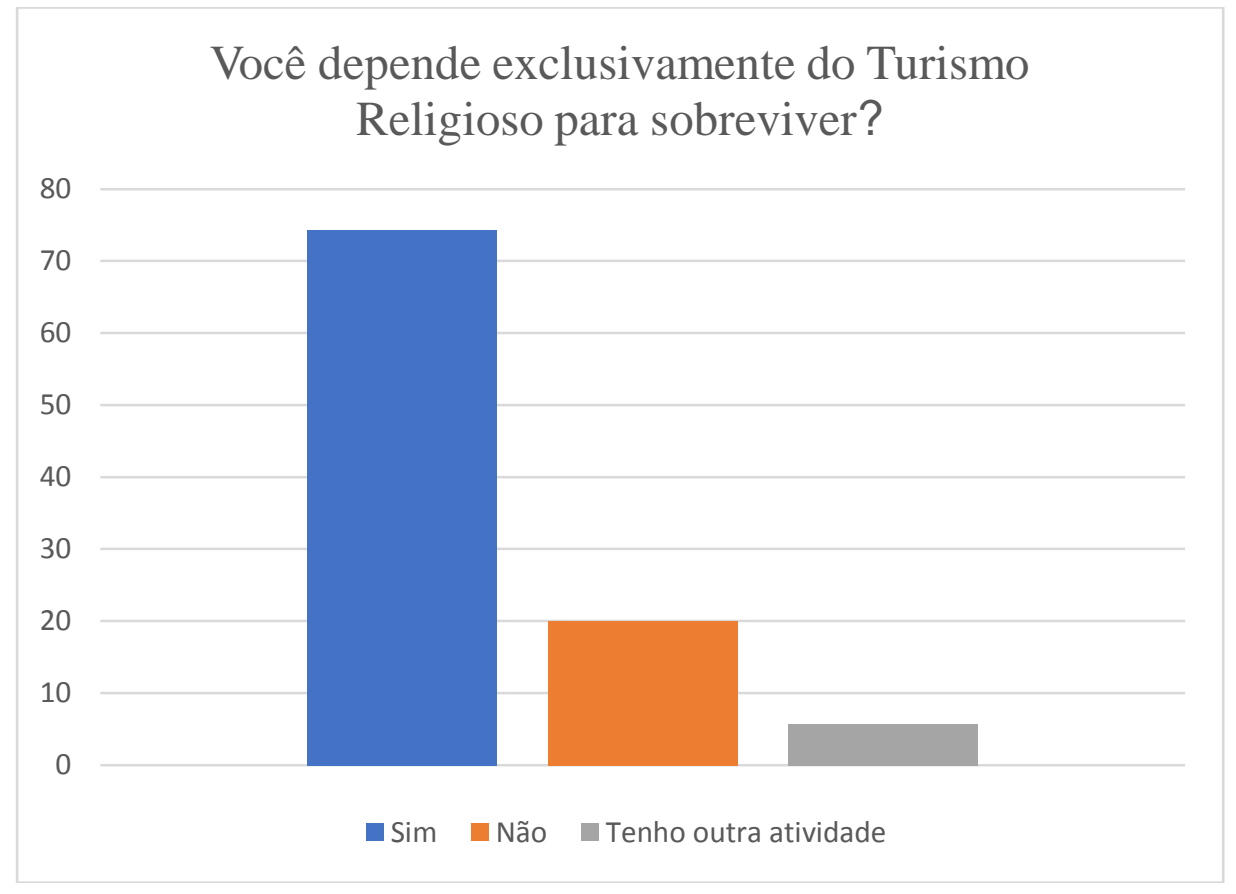

Fonte: Dados da Pesquisa (2021)

No segundo gráfico, observa-se que a maioria dependem exclusivamente do turismo religioso para sobreviver, $20 \%$ tem outra atividade, dentre essas algumas pessoas tiveram que realizar outra atividade pois com a parada do turismo, se tornou necessário obter outra fonte de renda e apenas $6 \%$ não depende exclusivamente do turismo religioso. Nessa perspectiva o turismo religioso acrescenta ganhos econômicos na qualidade de vida das pessoas que vivem no local, pois se constitui de um seguimento que possibilita aos visitantes o espairecer, relacionar com outro contexto e ter novas visões de mundo (PEREIRA, 2008).

No gráfico (3), é apontado o Turismo religioso, bem como seu crescimento, visto que a cidade é voltada para essa modalidade de turismo, é importante destacar que esse crescimento, faz com que a cidade se torne ainda mais atrativa.

Para Santos (2018), as gestões municipais do Brasil têm tido um molhar mais atento aos turismos religiosos, investindo nessa categoria, fazendo reformas e ampliando atrações, entre outros aspectos, pois percebeu a geração de renda e empregos.

Gráfico 3- O que você acha sobre o turismo religioso quanto ao seu crescimento? 


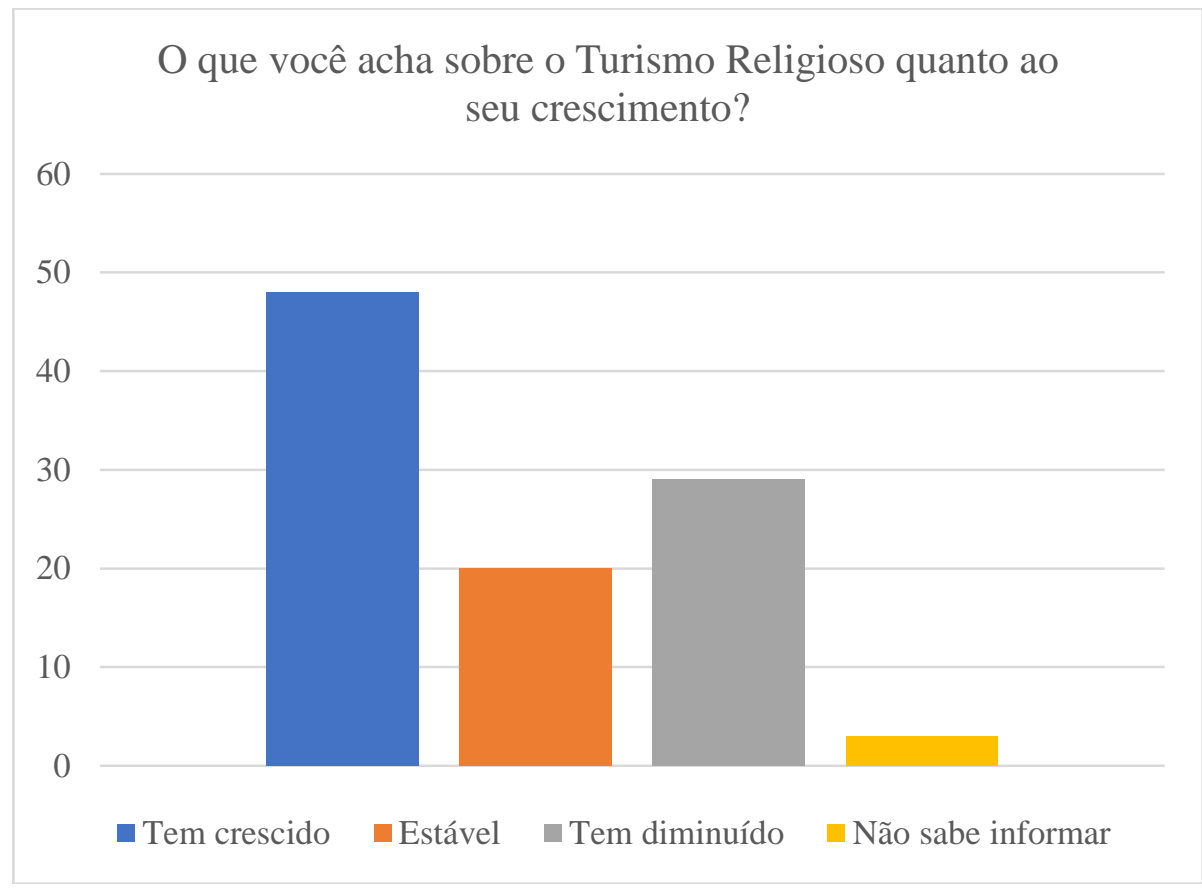

Fonte: Dados da Pesquisa (2021).

Segundo os dados apresentados, o Turismo religioso tem crescido, para grande parte dos participadores da pesquisa, porém, alguns fatores fizeram com que esse setor desce uma cessada. Nos últimos tempos, o turismo estava desenvolvendo-se, entretanto, esse crescimento diminuiu, pois, enfrenta-se uma pandemia mundial. Para 48,0\% dos participadores, Com o desenvolvimento da cidade o turismo estava crescendo. para $29.0 \%$ tem diminuído, ocasionado pelo covid-19. para 20,0\% está estável e 3\% não souberam informar.

No gráfico (4), busca-se saber sobre as vendas, se os pesquisados conseguiram mantê-las durante essa crise do corona vírus?. Em sua maioria, 54,3\% responderam que não conseguiram manter as vendas, $37,1 \%$ responderam que conseguiram parcialmente, e apenas $8,1 \%$ responderam que conseguiram.

Desse modo, pesquisas mostram que as primeiras categorias que sofreram perdas econômicas durante o período de pandemia da covid-19, foram as de turismo; isso em decorrência de que as medidas adotadas para o não contágio do vírus é de isolar-se socialmente (TOMÉ, 2020). Mesmo um ano após o início da epidemias, muitas cidades ainda tem como estratégia o fechamento do comércio para evitar que o vírus se 
propague, essa decisão tem um forte impacto para vendedores, que dependem exclusivamente das vendas para conseguir sobreviver. Essa decisão afetou de maneira significativa os vendedores, de modo que esses fechamentos de comércio, impossibilitou as vendas nesse período, por serem produtos considerado não essenciais ocasionando essa queda.

Gráfico 4- Está conseguindo manter as vendas durante a crise do corona vírus?

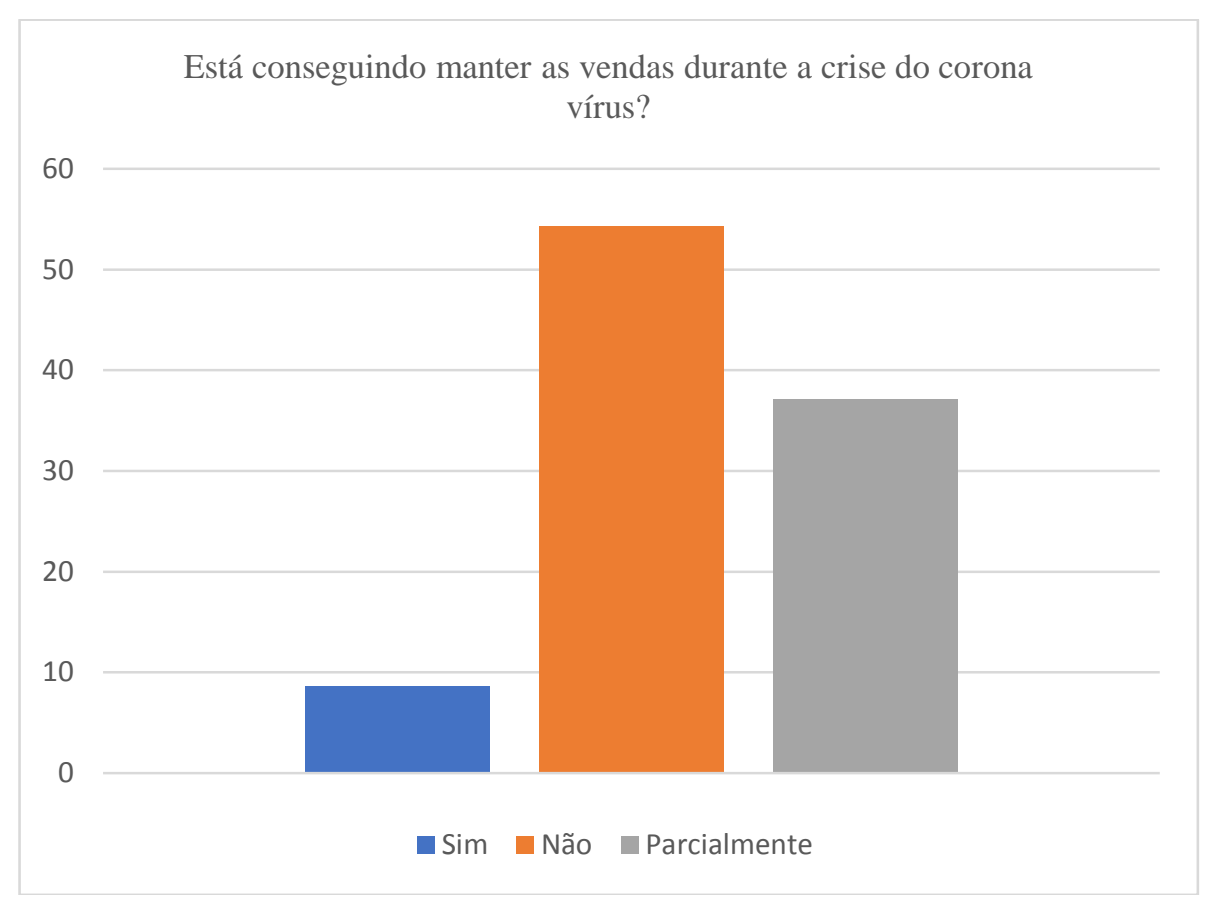

Fonte: Dados da Pesquisa (2021).

A queda nas vendas nesse período chegou a $74 \%$ durante a pandemia como mostrado no gráfico (5), 37,1\% estão parcialmente, e apenas $8,6 \%$ conseguem manter as vendas. 


\section{Gráfico 5- Em relação as vendas durante a pandemia de $\mathbf{0}$ a 100 houve queda de} quantos por cento?

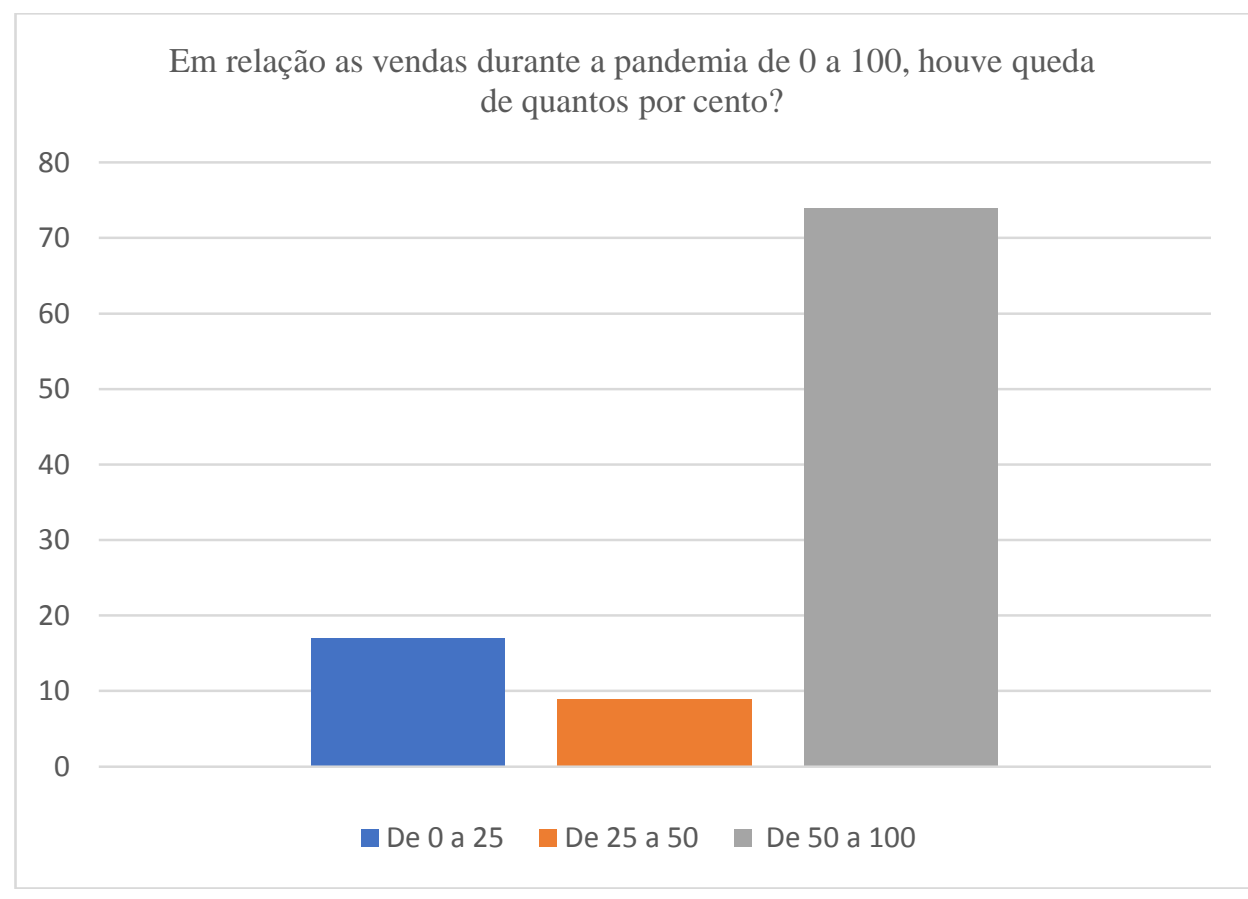

Fonte: Dados da Pesquisa (2021).

O gráfico (6), mostra parcialmente o número de pessoas que tiveram que utilizar de estratégias para conseguir ter sucesso nas vendas e não ficar no vermelho. $40 \%$ disseram que sim e $60 \%$ disseram que não. Podemos refletir que as estratégias de vendas, são de grande importância para o crescimento de qualquer categoria comercial, e é o que se diferencia de uma empresa para outra, com os objetivos de manter clientes fiéis e conquistar novos (FIGUEIREDO, 2016). 
Figura 6- Teve que criar estratégia para conseguir vender?

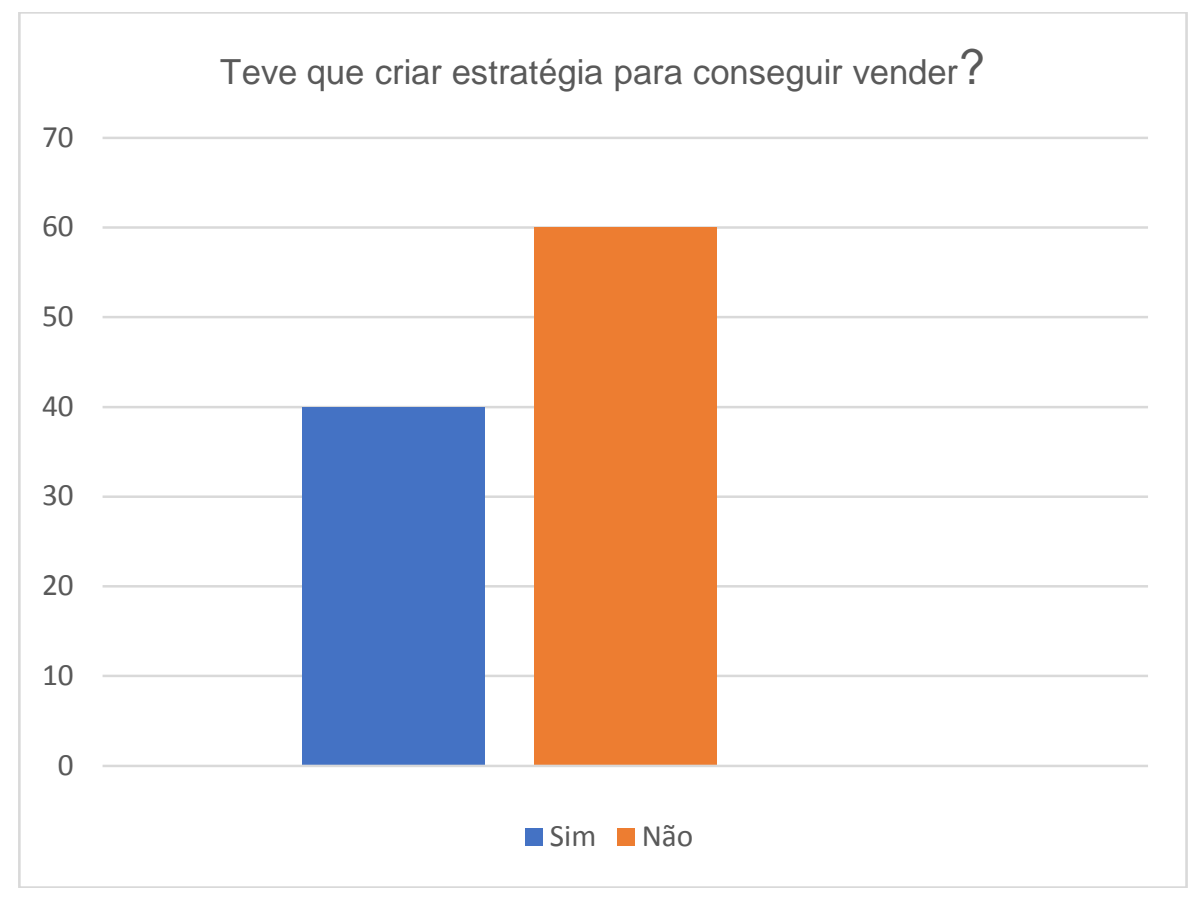

Fonte: Dados da Pesquisa (2021)

Quando perguntado se houve melhora nas vendas no gráfico (7), 74,3\% responderam que não houve melhora nesse período de um ano. 14, 3\% sim, 8,6\% Talvez e 2,9\% não souberam informar. Segundo Bernardes (2020), o atual contexto vive um período de pandemia que atinge tanto as pequenas como as grandes empresas, pois passaram grande parte do tempo de portas fechadas, em grande número ouve falência e poucos ramos tiveram ganhos. 
Figura 7- Houve melhora nas vendas após o início do período de vacinação?

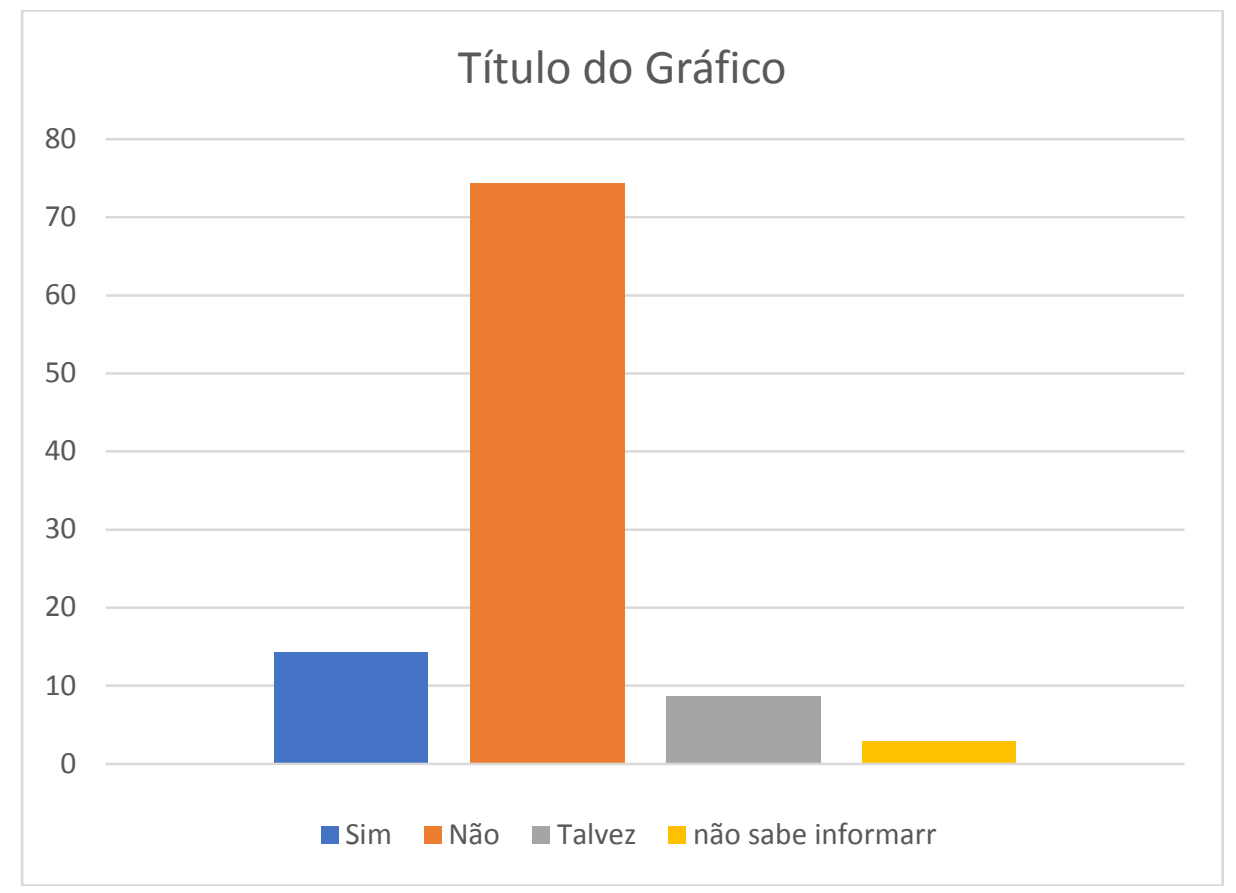

\section{Fonte: Dados da Pesquisa (2021)}

Muitas empresas vivem a incertezas nesse período, se irá dar continuidade ou não, sabe-se com a vacinação em massa há uma possibilidade de melhora, porém o cenário ainda é crítico e número de contágios é alto. No gráfico (8), $40 \%$ conseguem manter o negócio por mais um se a situação assim permanecer, $17,1 \%$ não, 11,4\% dificilmente e 31,4\% talvez. É necessário que as empresas antecipem estratégias e que se atentem em relação a continuação ou não de seu negócio, para que os prejuízos não aconteçam ou que pelo menos sejam pequenos (BERNARDES, 2020). 
Gráfico 8- Diante de todas as restrições impostas pelo período pandêmico foi possível manter o negócio por mais um ano?

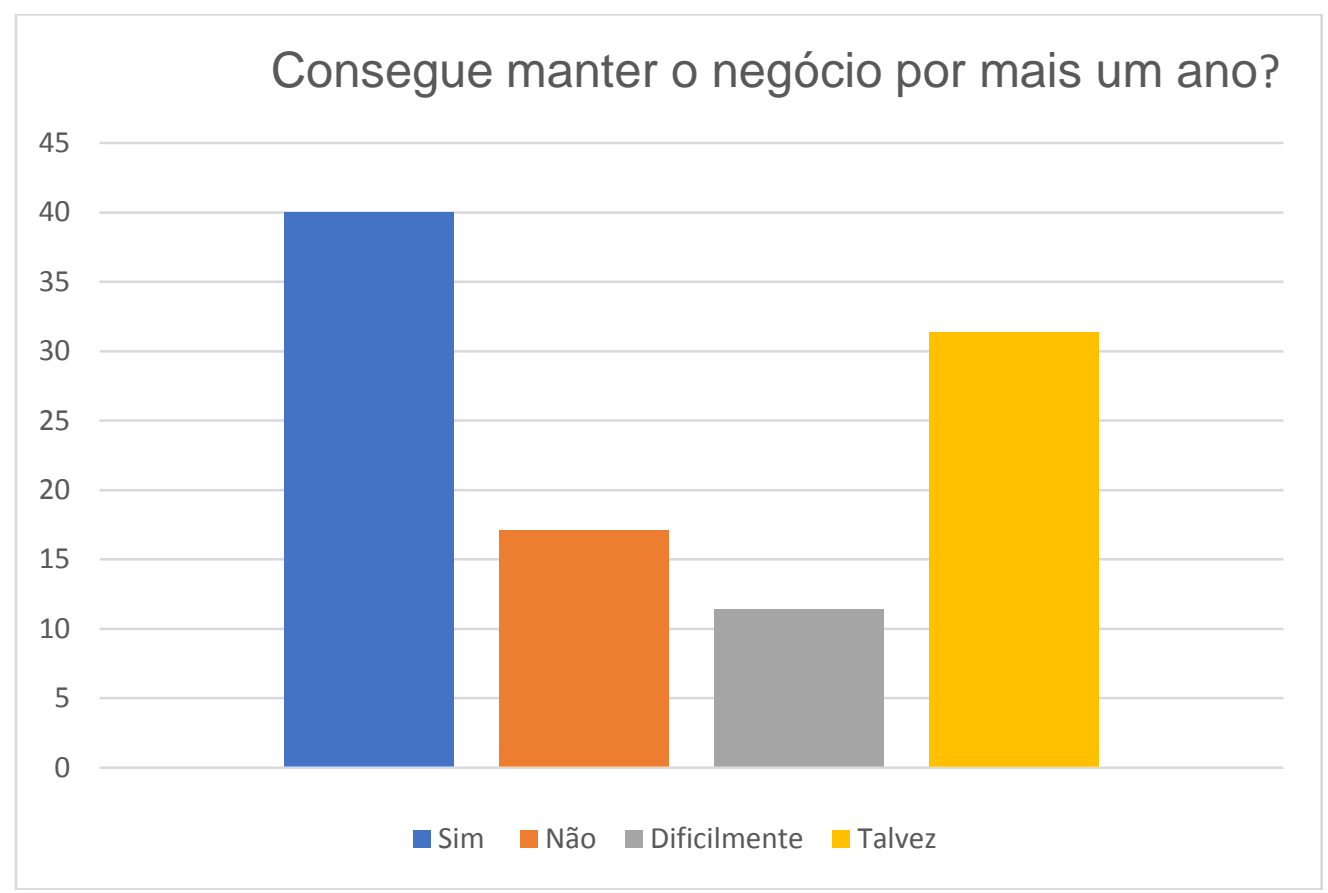

Fonte: Dados da Pesquisa (2021).

No gráfico (9) é apontado a diminuição na compra dos produtos $97 \%$, com a parada do turismo não há como renovar o estoque de produtos, pois os produtos não estão tendo saída. Em decorrência da pandemia algumas empresas tiveram consequências nos setores de estoque, isso porque os produtos não estavam vendendo, para se ter noção antes ocorrido os armazéns que estocavam os produtos chegavam a 95 $\%$ de sua capacidade, agora com os números das vendas atual essa porcentagem despencou (BOLO, 2020). 
Gráfico 9- Houve diminuição na compra de novos produtos?

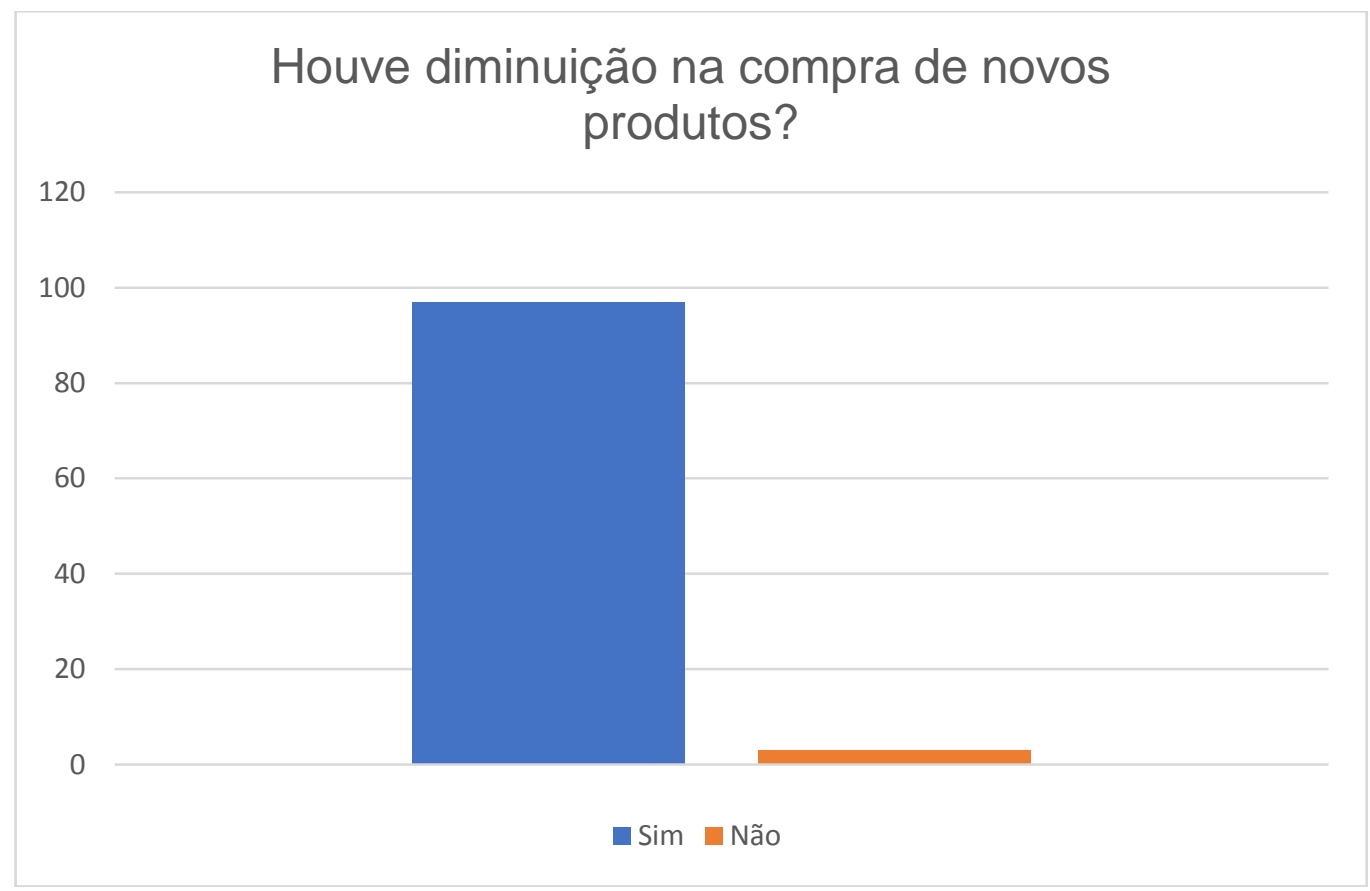

Fonte: Dados da Pesquisa (2021)

Mesmo antes da pandemia algumas empresas já utilizavam as redes sociais para divulgar seus produtos, com o início da epidemia, os comerciantes, que antes não utilizavam as redes socias para vender seus produtos, passaram a utilizar essa ferramenta como estratégia para conseguir vender nesse período. como mostrado no gráfico (10), o número de pessoas que utilizam os meios tecnológicos é de 62,9\% nesse período e 37,1\% não utilizam esses meios para vender. A divulgação de produtos é uma estratégia inteligente para a competitividade atual, assim, divulgar é mostrar ao consumidor a relevância do produto e chamar a atenção dele, resultando no aumento das vendas, além disso é bom entrar em contato depois com o cliente para mostrar a importância do feedback (FIGUEIREDO, 2016).

Nota-se a importância na criação de estratégias, para dar continuidade aos negócios, utilizando recursos acessíveis tais como: redes sociais, que atualmente, todos têm acesso. 
Figura 10- Chegou a utilizar ou está utilizando redes sociais para a divulgação dos produtos?

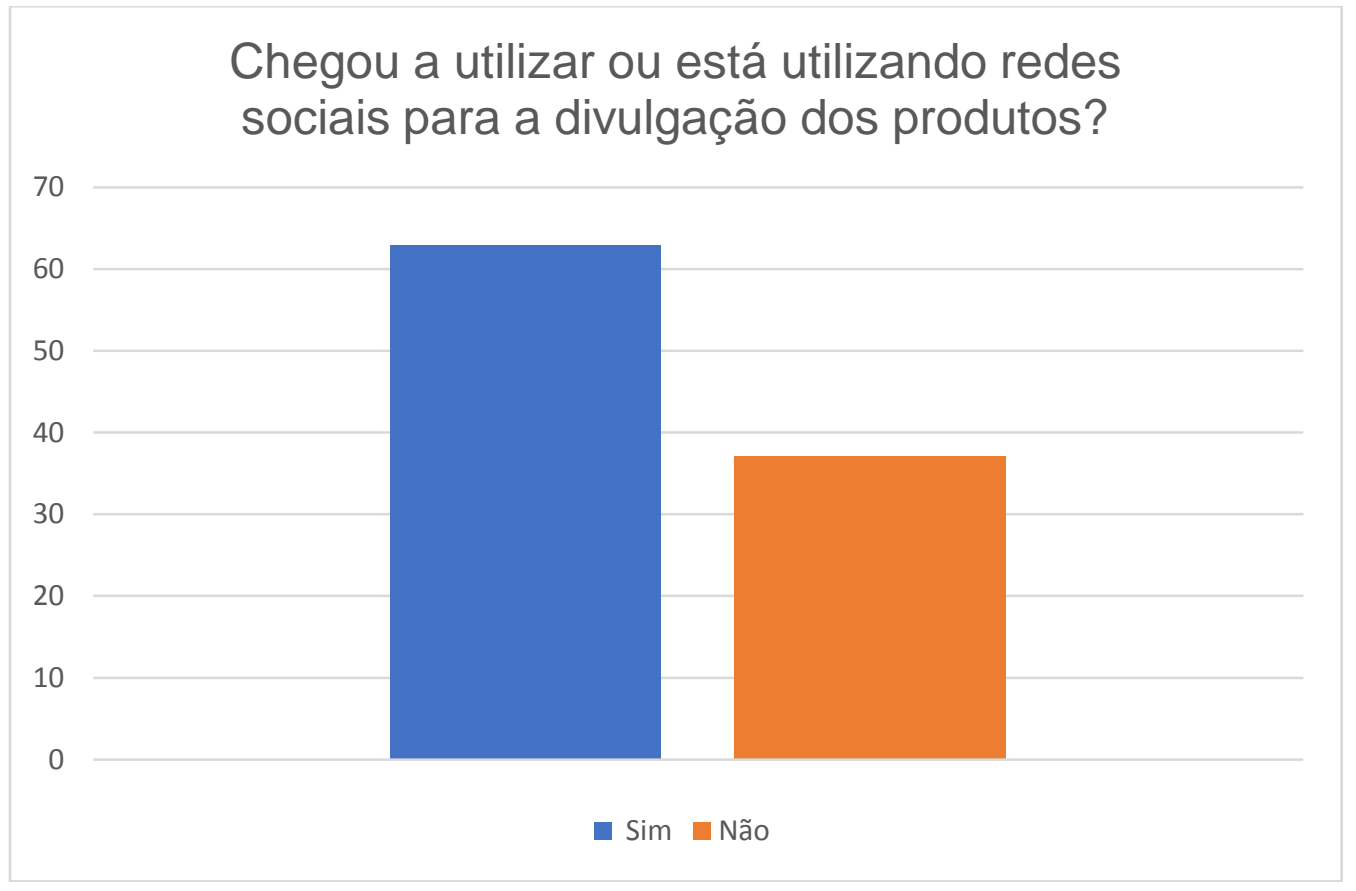

Fonte: Dados da Pesquisa (2021)

\subsection{Análise das entrevistas com comerciantes da cidade de Bom jesus da Lapa - BA}

Por conta do atual momento de pandemia, foram feitas entrevistas com duas pessoas dos seguimentos de comércio de Bom Jesus da Lapa para além de entender a importância compreender as consequências do momento pandêmico. Nesse intuito foi feito o seguinte questionamento: como está sendo para enfrentar a nova realidade no negócio em plena pandemia?

Os entrevistados relatam que está cada vez mais difícil lidar com a realidade atual, isso porque o fluxo de pessoas que utilizam o serviço caiu consideravelmente impactando drasticamente o comércio e a economia local e mundial. O entrevistado E1 ressalta:

Está sendo bem difícil, estamos passando aí por um momento crítico, praticamente dois anos sem trabalhar. (Entrevistado E1, 2021)

O entrevistados E2 Em consonância: 
Houve uma queda no número de ocupações em hotéis, pousadas e demais hospedarias, a compra de produtos não essenciais tornou-se difícil, com a da pandemia tornou-se impossível, viagens, comemorações, celebrações, encontros, e assim, sucessivamente. Com mais de um ano de pandemia, as empresas buscam-se reinventar e manter seu negócio por mais tempo, por esse motivo, estratégias são criadas para que continuem suas atividades. Por essa razão, tenta-se entender: Como está sendo possível manter o empreendimento em plena pandemia?

Segundo E1:

Então, devido a esse momento crítico, a gente tem que tá adaptando né, buscando empreender e fazendo novos investimentos na área de marketing para melhor divulgação. (Entrevistado E1, 2021).

E2 acrescenta:

Nossa empresa não depende totalmente do turismo, por esse motivo consegue-se manter, não há estratégia! (Entrevistado E2, 2021)

Nessa perspectiva Holanda (2020) aponta que:

O atual momento é de pesquisa, planejamento e gestão de crise em todos os setores afetados com a pandemia da COVID-19. É preciso ações enérgicas e investimentos pontuais, com bom uso dos recursos públicos, para reduzir o número de casos da COVID-19, ampliar e aperfeiçoar a condição de atendimento nos hospitais e postos de saúde e seguir os novos protocolos de biossegurança. $\mathrm{O}$ mundo continua preocupado em salvar vidas. Por outro lado, é fundamental repensar a retomada econômica das cidades, e o setor de Turismo possui uma grande parcela de contribuição nesse aspecto. Os planejadores turísticos precisam repensar as suas ações, adaptar-se ao contexto, ser criativo, fazer planejamentos colaborativos, inserir os residentes no processo de planejamento, definir perfis de turistas almejados, elaborar novos roteiros e aperfeiçoar os existentes, despertar imaginários sobre o destino. (p.14)

Nesse aspecto, as cidades que tem turismo religioso em grande maioria depende exclusivamente do capital resultante dela, é onde entra o papel do estado com medidas de auxilio econômicos para a subsistência dos envolvidos, e também repensar uma importante retomada desse gerador econômico, mas que seja de forma segura. 


\section{Considerações Finais}

O intuito dessa pesquisa foi entender a importância do turismo religioso para a população lapense, que desde março de 2020, não só na cidade como também no mundo todo, foi atingida pelo novo corona vírus possibilitou entender tanto a importância, quanto o impacto que causou no comércio da cidade e dessa forma, saber se estes utilizaram estratégias para continuar com o negócio. Foi aplicado um questionário com 35 pessoas, dentre elas, vendedores ambulantes e de barracas e entrevista com dois comerciantes, escolhidos por trabalhar diretamente com o turismo religioso para responder a seguinte questão: Compreender a importância do turismo religioso para Bom Jesus da Lapa-Ba e quais as consequências e estratégias utilizadas para movimentar o mercado da mesma, com a nova realidade? essa investigação constatou que o turismo religioso é de total importância para Bom Jesus da Lapa-Ba e para todos os habitantes seja de maneira direta ou indireta, pois é o fator que movimenta a economia. Ademais boa parte desses seguimentos comerciais sofreram consequências drásticas em decorrência da pandemia. Partes do público que responderam o questionário assinalaram que utilizam estratégias nesse período para manter as vendas. O turismo religioso é um grande gerador de empregos para a cidade, famílias inteiras dependem dele para o sustento, em período de romaria quando o aumentam o fluxo de pessoas na cidade, esses comerciantes de barracas costumam contratar pessoas para conseguir atender o público intenso. Mesmo que de forma indireta, outros setores necessitam do turismo, pois com esse aumento de pessoas, consequentemente outros serviços serão utilizados. A pandemia trouxe consequências como: Empresas fechando no vermelho, pois com a quantidade menor de pessoas na cidade, pessoas foram demitidas, isso traz malefícios para a economia local. Quando observado o período antes e pós pandemia, é notória diferença, em todos os setores tanto nas empresa e para os vendedores ambulantes, por ser uma cidade turística mesmo que não exista uma estratégia para as vendas, sempre havia público para comprar, após a pandemia, com a queda do turismo houve diminuição de compra. Em suma, por conta dos impactos provocados pela pandemia, os comerciantes tiveram que criar estratégias para conseguir manter sua renda, de acordo com a pesquisa, um dos métodos utilizados pelos 
autônomos foi a divulgação dos produtos nas redes sociais, além disso, uma outra parte optou por outras atividades remuneradas muitos optaram por realizar outra atividade, para conseguir sustentar-se.

Diante do exposto nota-se a importância do turismo religioso na cidade e as consequências que geradas por sua parada, é fundamental aprofundar-se no assunto que irá servir de base para futuras pesquisas voltados para esse setor necessário para toda sociedade, que enfrenta dificuldades geradas pelo vírus do covid-19, em que há poucos estudos na área.

\section{Referências}

ALMEIDA, Lorrana Laila Silva de; ENOQUE, Alessandro Gomes; JÚNIOR, Antônio de Oliveira. Turismo religioso como fonte de desenvolvimento local: um estudo acerca da produção do espaço urbano a partir da prática turística religiosa. Marketing \& Tourism Review. v. 4 n. 2 (2019): v.4, número 2. 2019 Disponível em: < https://revistas.face.ufmg.br/index.php/mtr/article/view/5538.>.

ARDIGÓ, Carlos Marcelo; et al. O turismo religioso e o processo de comunicação de marketing: um estudo do santuário de santa paulina em nova trento - sc. Revista Turismo - Visão e Ação - Eletrônica, Vol. 18 - n. 2 - mai. - ago. 2016. Disponível em: $<$ https://www.redalyc.org/articulo.oa?id=261056060007>

ARAÚJO, Manoel Antônio Oliveira; JESUS, Samira Nayara Gonçalves de; PIRES, Paulo Fernando de Oliveira. Hotelaria: práticas gerenciais em empreendimentos da cidade de Bom Jesus da Lapa. Caderno de Ciências Sociais Aplicadas. Bom Jesus da Lapa, 2016.

AZEVEDO, Denio Santos; HOLANDA, Francisco Sandro Rodrigues; LIBERATO, Mônica Maria. Impactos dapandemia da Covid-19 nos Empreendimentos Turísticos de Aracaju/Sergipe/Brasil. Revista Interdisciplinar em Cultura em Sociedade. (RICS), São Luís, v. 6, n. 2, p. 209-226, jul./dez. 2020. Disponível em: http://www.periodicoseletronicos.ufma.br/index.php/ricultsociedade/article/view/15825.

BAUER, M W.GEORGE G. Pesquisa qualitativa com texto, imagem e som -13. ed. Petrópolis, RJ:Vozes, 2015.

BESSA, Thiago. Encontro da embratur discute turismo religioso em Juazeiro do Norte. pousadasombradojua.com.br. 2015. Disponível em:

$<$ https://www.pousadasombradojua.com.br/encontro-da-embratur-discute-turismoreligioso-em-juazeiro-do-norte/> Acessado em: 07/05/2021.

BERNARDES, Juliana Reis; LIMA, Thais Cristina Pereira; SILVA, Bárbara Letícia de Souza. Os impactos financeiros da covid-19 nos negócios. Revista da FAESF, vol.4. Número especial COVID 19, 2020. Disponível em:< 
https://www.google.com/url?sa=t\&source=web\&rct=j\&url=https://www.faesfpi.com.br/ revista/index.php/faesf/article/download/115/101\&ved=2ahUKEwi3kNOoye3wAhWcH bkGHbUDDWUQFjAAegQIBhAC\&usg=AOvVaw0mGOgQ9Ab1TXzfTadoLhzY\&cs hid $=1622246053827>$.

BOLO, Gianni Arnold Pasache. O Impacto do Covid 19 nos Processos de Distribuição. 2020. Disponível em:< https://www.google.com/url?sa=t\&source=web\&rct=j\&url=https://engemausp.submissa o.com.br/22/arquivos/333.pdf\&ved=2ahUKEwjT7t-Vy-

3wAhWqHbkGHbzaBaoQFjAAegQIBRAC\&usg=AOvVaw2ia9JC42BQyhV2tEKCN0 ns>.

BRISOLA, Elisa Maria Andrade; MARCONDES, Nilsen Aparecida Vieira. Análise por Triangulação de métodos: Um Referencial Para Pesquisas Qualitativas. Revista Univap - revista.univap.br. São José dos Campos-SP-Brasil, 2014. Disponível em:< https://revista.univap.br/index.php/revistaunivap/article/view/228>.

COSTA, Luciane Cunha da; PEREIRA, Tatiane Morais; RIBEIRO, Roberto Pazos; SANTOS, José Roberto Araújo dos. Turismo religioso: análise e tendências. V Seminário da Associação Nacional de Pesquisa e Pós-Graduação em Turismo. Belo Horizonte, 2008.

DESLANDES, Suely Ferreira. Pesquisa social. - Petrópolis, Rio de Janeiro: vozes 1994.

DIAS, Isabel Nunes. Turismo Cultural e Religioso no Distrito de Coimbra: Mosteiros e Conventos: Viagem entre o Sagrado e Profano. Coimbra, 2010.

FIGUEIREDO, Ana Carolina Gimenes. et.al. Estratégia de vendas: um estudo de caso na cooperativa de trabalho médico UNIMED de Lins/SP. Revista científica do Unisalesiano. São Paulo, 2016. Disponível em:

https://www.google.com/url?sa=t\&source=web\&rct=j\&url=http://www.salesianolins.br/ universitaria/artigos/no15/artigo126.pdf\&ved=2ahUKEwijpbKw1-

3wAhUSD7kGHU33C3YQFjAAegQIAxAC\&usg=AOvVaw1bgSRuWWu$7 \mathrm{sSmn0DuvEy7.}$

GIL, Antonio Carlos. Como elaborar projetos de pesquisa. 4. ed. São Paulo: Atlas, 2008.

KHATIB, Ahmed Sameer El. Economia versus epidemiologia: uma análise do tradeoff entre mercados e vidas em tempos de covid-19. São Paulo, 2020.

MANZINI, Eduardo José. Uso da entrevista em dissertações e teses produzidas em um programa de pós-graduação em educação. Revista percurso. Maringá, 2012.

MARCONI, M. De A.; LAKATOS, E. M. Técnicas de pesquisa. São Paulo: Atlas, 2007. 
MINAYO, M. C. S. (Org). Pesquisa social: teoria, método e criatividade. Petrópolis: vozes, 1995.

NOGUEIRA, Iannic Costa. Eventos religiosos como promotores de desenvolvimento Regional - o caso de juazeiro do norte. 2013. 87 f. TCC (graduação em Ciência Econômicas) - Universidade Federal do Ceará, Faculdade de Economia, Administração, Atuária e Contabilidade, Fortaleza-CE, 2013.

PEREIRA, Luiz Carlos Bresser. O conceito histórico de desenvolvimento econômico.

Fundação Getúlio Vargas. 2006. Disponível em:

<http://www.bresserpereira.org.br/papers/2006/06.7-

conceitohistoricodesenvolvimento.pdf >

PEREIRA, Maria C. A mobilidade urbana e o turismo religioso em Juazeiro do

Norte/Ceará. Jus, 2015. Disponível em: <https://jus.com.br/artigos/36874/a-

mobilidade-urbana-e-o-turismo-religioso-em-juazeiro-do-norte-ceara.> .

PINTO, Andrei Guimarães . O turismo religioso em Aparecida (SP): aspectos

históricos, urbanos e o perfil dos romeiros. Rio Claro, São Paulo: 2006.

RIBEIRO, Cristiane Menezes. Turismo Religioso: Fé, Consumo E Mercado. E-

Revista Facitec, v.5, n.1, Art.6, ago-dez 2010. Disponível em:

$<$ http://www.facitec.br/erevista/index.php?option=com_content\&task=view\&id=9\&Ite $\operatorname{mid}=2>$.

RODRIGUES, Juliana. Romaria de Bom Jesus da Lapa é tema de encontro na

Câmara de Vereadores. sudoestebahia.com. 07/06/2019. Disponível em:

$<$ https://www.sudoestebahia.com/noticias/24093-2019/06/07/romaria-de-bom-jesus-dalapa-e-tema-de-encontro-na-camara-de-vereadores> Acessado em: 06/04/2021.

SANTOS, Jonas Félix e; SEVERO, Fágner Evangelista. Marketing e turismo religioso: as influências da fé cristã na economia de camboriú e nova trento-sc.

Santos, São Paulo. 2018.

SILVA, Kely Cristina Mendes da. A importancia do Turismo para o desenvolvimento econômico para o estado do Espirito Santo. Vitória, 2004.

Disponível em:

$<$ https://www.google.com/url?sa=t\&source=web\&rct=j\&url=https://observatoriodoturis mo.es.gov.br/Media/observatorio/Publicacoes/Outras/Monografias/KELYCRISTINAM ENDESDASILVA.pdf\&ved=2ahUKEwjv1 pa53e3wAhVNFrkGHfkLAZUQFjAAegQI AxAC\&usg=AOvVaw04qj0slYjztxxfB8BORRNv>.

SITE SCTURISMO.COM.BR. Nova Trento. 04/08/2019. Disponível em: <https://www.scturismo.com.br/nova-trento/ > Acessado em: 08/04/2021. 
SITE VEJA.ABRIL.COM.BR. Romaria de Aparecida. 12/10/2012. Disponível em: <https://veja.abril.com.br/galeria-fotos/romaria-de-aparecida/> Acessado em: 06/04/2021. STEIL, Carlos Alberto. Romeiros e turistas no santuário de Bom Jesus da Lapa. Porto Alegre. 2003. 